\title{
Association between the -1562 C/T MMP-9 polymorphism and cerebrovascular disease in a Polish population
}

\section{Polimorfizm -1562 C/T genu MMP-9 w chorobach naczyniowych mózgu w populacii polskiej}

Piotr Szczudlik', Anna Borratyńska²

'Department of Neurology, Medical University of Warsaw, Warsaw, Poland

2Department of Neurology, Jagiellonian University Medical College, Krakow, Poland

Neurologia i Neurochirurgia Polska 2010; 44, 4: 350-357

\begin{abstract}
Background and purpose: Matrix metalloproteinase 9 (MMP-9) is an endopeptidase degrading extracellular matrix. There is growing evidence that changes in extracellular matrix play an important role in vascular pathology, especially in cardiovascular and cerebrovascular disease. Previous studies have demonstrated that MMP-9 activity is controlled by $-1562 \mathrm{C} / \mathrm{T}$ polymorphism. Genotypes with T allele (CT, TT) have higher enzymatic activity. Thus, this polymorphism could be responsible for the higher risk for cerebrovascular disease and death. The aim of this study was to assess the significance of $M M P-9$ polymorphism as a risk factor for cerebrovascular disease in a Polish population.
\end{abstract}

Material and methods: A total of 775 consecutive patients with a diagnosis of cerebrovascular disease (ischaemic stroke, intracerebral haemorrhage, subarachnoid haemorrhage) admitted to the Stroke Unit, Jagiellonian University, Krakow, Poland between 2000 and 2004 were studied and compared with 766 matched controls. The polymorphism was studied by polymerase chain reaction (PCR) and restricted enzyme digestion.

Results: Among 418 patients with ischaemic stroke of various aetiologies and among 146 patients with primary intracerebral haemorrhage and 211 patients with subarachnoid haemorrhage due to ruptured intracranial aneurysm, statistical analysis did not show a significant difference between occurrence of CC, CT, TT genotypes or C and T

\section{Streszczenie}

Wstęp i cel pracy: Metaloproteinaza 9 (MMP-9) jest endopeptydazą degradującą macierz zewnątrzkomórkową. Istnieje coraz więcej dowodów naukowych potwierdzających ważną rolę zmian w macierzy zewnątrzkomórkowej w chorobach naczyniowych, a szczególnie w chorobach serca i naczyń mózgowych. Badania dowiodły, że aktywność MMP-9 jest zależna od polimorfizmu -1562 C/T. Genotypy z allelem T (CT, TT) wykazują większą aktywność enzymatyczną, co może przyczyniać się do znaczenia tego polimorfizmu jako czynnika ryzyka chorób naczyniowych mózgu i śmierci. Celem tego badania była analiza związku wariantów polimorficznych genu MMP-9 z chorobami naczyniowymi mózgu w badanej populacji polskiej.

Materiał i metody: Badano łącznie 775 pacjentów przyjętych na Oddział Udarowy Kliniki Neurologii Uniwersytetu Jagiellońskiego w latach 2000-2004 z rozpoznaniem choroby naczyń mózgowych (tj. udaru niedokrwiennego, krwotoku śódmózgowego lub krwotoku podpajęczynówkowego) oraz 766 osób z grupy kontrolnej. Polimorfizm genu MMP-9 badano za pomocą techniki PCR i trawienia przy użyciu enzymu restrykcyjnego.

Wyniki: Analiza statystyczna nie wykazała istotnych różnic w występowaniu genotypów CC, CT i TT ani alleli C i T u 418 chorych na udar niedokrwienny o różnej etiologii, 146 osób z pierwotnym krwotokiem śródmózgowym ani u 211 chorych z krwotokiem podpajęczynówkowym z pęk-

Correspondence address: Piotr Szczudlik, Klinika Neurologii, Warszawski Uniwersytet Medyczny, ul. Banacha la, 00-097 Warszawa, e-mail: pszczudlik@wum.edu.pl

Received: 18.08.2009; accepted: 25.05.2010 
alleles in patients with stroke of various aetiology compared with controls.

Conclusions: We found no association between the $-1562 \mathrm{C} / \mathrm{T}$ $M M P-9$ polymorphism and ischaemic stroke, subarachnoid haemorrhage or spontaneous intracerebral haemorrhage in the studied Polish population.

Key words: $-1562 \mathrm{C} / \mathrm{T}$ polymorphism of $M M P-9$ gene, matrix metalloproteinase-9, cerebrovascular disease.

\section{Introduction}

Matrix metalloproteinase 9 (gelatinase B, MMP-9) is an endopeptidase degrading extracellular proteins, mostly gelatine and collagen type IV (native protein). MMP-9 can be expressed by many cells, especially by endothelial cells, monocytes and macrophages. This enzyme plays an important role in both physiological (embryogenesis, angiogenesis) and pathological (carcinogenesis, arthritis, pulmonary diseases) processes [1]. Previous studies have demonstrated that MMP-9 activity is controlled by several $M M P-9$ gene polymorphisms [2]. The MMP-9 gene is located on chromosome $20 \mathrm{q} 11.2-\mathrm{q} 13$ and several polymorphisms in the promoter, coding, and untranslated regions (UTR) have been reported [3-5], with the $-1562 \mathrm{C} / \mathrm{T}$ polymorphism most extensively studied [6]. This polymorphism in the promoter region of the $M M P-9$ gene is probably functional in transcriptional regulation [2]. A recent study revealed that the $\mathrm{CC}$ genotype is responsible for lower activity of MMP-9 and genotypes with the T allele (CT, TT) are responsible for higher activity [7]. The aim of our study was to assess the significance of the $-1562 \mathrm{C} / \mathrm{T}$ polymorphism of the $M M P-9$ gene as a risk factor for different types of cerebrovascular diseases, i.e. ischaemic stroke, $\mathrm{ICH}$ and $\mathrm{SAH}$ from ruptured aneurysm.

There is growing evidence that extracellular matrix plays an important role in cardiovascular and cerebrovascular diseases [8]. Higher expression of $92-\mathrm{kDa}$ gelatinase (MMP-9) using in situ zymography was found in atherosclerotic plaques obtained during endarterectomy or autopsy [9]. Increased expression of MMP-9 using in situ zymography was also found in the wall of cerebral aneurysms [10]. The concentration of MMP-9 in plasma correlates with neurological deficit and infarct volume of stroke patients [11], as well as with the risk of haemorrhagic transformation of cardioembolic stroke $[12,13]$. Increased concentration of niętego tętniaka wewnątrzczaszkowego w porównaniu z osobami z grupy kontrolnej.

Wnioski: Nie odnaleziono związku polimorfizmu $-1562 \mathrm{C} / \mathrm{T}$ genu $M M P-9$ z występowaniem udaru niedokrwiennego o różnej etiologii, krwotoku podpajęczynówkowego i pierwotnego krwotoku śródmózgowego w badanej populacji polskiej.

Słowa kluczowe: polimorfizm -1562 C/T genu MMP-9, metaloproteinaza 9, choroba naczyń mózgowych.

MMP-9 was also found in plasma of patients with intracerebral haemorrhage (ICH) [14].

The effect of the $-1562 \mathrm{C} / \mathrm{T} M M P-9$ polymorphism on the risk of cerebrovascular diseases was studied only in patients with subarachnoid haemorrhage ( $\mathrm{SAH})$ from ruptured aneurysm, showing negative results $[15,16]$.

\section{Material and methods}

The study population consisted of 1016 unrelated patients with a diagnosis of cerebrovascular disease prospectively recruited at the Stroke Unit, Neurology Department, University Hospital, Krakow, Poland between 2000 and 2004. The Unit serves as a stroke emergency centre for one district of Krakow and as a referral centre for a region of 1.5 million citizens. We excluded patients with coexisting cancer or not agreeing to participate in the study. Among 643 ischaemic stroke patients selected from 714 patients, 225 had a stroke of unknown aetiology and were excluded, leaving 418 patients eligible for the study. We also included 211 patients with SAH (out of 281 patients). We also involved 146 patients with ICH (out of 182 patients). We studied 766 unrelated control individuals, free of clinically detectable cerebrovascular disease and without any stroke history, as well. They were recruited from consecutive spouses of the patients (30\%) or from the community. Controls were randomly matched from the beginning of the study for age ( \pm 2 years) and gender with patients for each studied group separately.

Ischaemic stroke aetiologies were diagnosed using TOAST criteria [17]. Only patients with established stroke aetiology were included in the study. The diagnosis of SAH was confirmed by computed tomography (CT), and/or lumbar puncture, and the diagnosis of ruptured saccular aneurysm was established by digital subtraction angiography (DSA) or angio-CT. ICH was diagnosed by CT. Vascular malformations were excluded by means of DSA or magnetic resonance (MR). 
Demographic data and vascular risk factors profile were collected for all patients and their controls in each study group. An individual was classified as having arterial hypertension if he/she met at least one of the following criteria: 1) the diagnosis of hypertension in the past medical history; 2) antihypertensive treatment prior to entry into the study; 3 ) systolic or diastolic blood pressure $\geq 140 \mathrm{~mm} \mathrm{Hg}$ or $\geq 90 \mathrm{~mm} \mathrm{Hg}$, respectively, on at least two different occasions (the first three days of hospitalization were not considered for the stroke patients). The history of ischaemic heart disease was based on medical history, examination of previous and current ECGs, and laboratory data. The diagnosis of atrial fibrillation was based on ECG findings during hospitalization, or on data from medical documentation with ECG-documented atrial fibrillation. Diabetes mellitus was defined by WHO criteria [18]. Family history of stroke was defined as the occurrence of stroke in first degree relatives. Smoking habits were defined as current smokers of $\geq 1$ cigarette per day, former smokers, or non-smokers. For statistical analysis, 'current' and 'former' smokers were pooled together.

The study was approved by the University Ethical Committee and was performed in accordance with the Helsinki Declaration.

Ten $\mathrm{mL}$ blood samples were collected from all patients and controls for probes with EDTA. Laboratory personnel, blinded to sample identity, performed the genetic analyses. The genotyping for $M M P-9$ polymorphism was established by polymerase chain reactions $(\mathrm{PCR})$ and restriction enzyme digestions using the method previously reported [3].

Data on quantitative characteristics are expressed as means \pm standard deviations (SD). Data on qualitative characteristics are expressed as percent values or absolute numbers, as indicated. Comparisons between groups were made with $\chi^{2}$ test (nominal data) or Student's t-test (interval data). A $p$-value $<0.05$ was considered statistically significant.

Hardy-Weinberg equilibrium was tested by the $\chi^{2}$ method. The sample sizes were calculated with a power of $80 \%$ to detect the difference between the frequencies of alleles at the 0.05 significance level. The association of the $-1562 \mathrm{C} / \mathrm{T} M M P-9$ polymorphism with the risk of cerebrovascular disease was investigated by means of logistic regression analysis. For multivariate risk predictors, adjusted odds ratios (ORs) are given with the $95 \%$ confidence intervals (CIs).

The calculations were performed using the data analysis software program SPSS 10 for Windows (SPSS Inc. 2000).

\section{Results}

We studied 96 stroke patients with large vessel disease (LVD) (23\% of all stroke patients), 100 stroke patients with small vessel disease (SVD) (24\% of all stroke patients), and 222 patients with cardioembolic stroke (CE) (53\% of all stroke patients). The control group consisted of 408 subjects. Patients with LVD and SVD stroke had hypertension, hypercholesterolaemia and diabetes more often than controls. Patients with CE stroke additionally more often had ischaemic heart disease and atrial fibrillation as compared to controls (Table 1). The CC, CT and TT genotypes of the MMP-9 gene, determined in 826 individuals, were in Hardy-Weinberg equilibrium for the total group and for patients with different stroke aetiologies and controls separately ( $p>0.1$ for each group).

The distribution of genotypes and alleles in patients with different ischaemic stroke aetiologies was similar to that in the controls (Table 1). Independent risk factors for SVD stroke were hypercholesterolaemia and hypertension, for LVD stroke were smoking, hypercholesterolaemia, and hypertension. Independent risk factors for $\mathrm{CE}$ stroke were hypercholesterolaemia, hypertension, ischaemic heart disease, and atrial fibrillation. Logistic regression analysis showed that genotypes with the $\mathrm{T}$ allele were not an independent risk factor for stroke of different aetiologies (Table 2).

One hundred and forty-six patients with ICH differed from their controls in respect of hypertension and hypercholesterolaemia. The distribution of the genotypes and alleles of the studied polymorphism was similar to that in the controls (Table 3). An independent risk factor was hypertension. Logistic regression analysis showed that genotypes with the $\mathrm{T}$ allele were not an independent risk factor for $\mathrm{ICH}$ (Table 4).

Patients with SAH more often had hypertension, diabetes and hypercholesterolaemia and were more often smokers (current and previous ones) (Table 3). Genotype and allele frequencies did not differ significantly between SAH patients and controls (Table 3 ). Independent risk factors were hypertension and smoking. Hypercholesterolaemia and ischaemic heart disease were independent factors decreasing the risk of SAH. Logistic regression analysis showed that genotypes with the $\mathrm{T}$ allele were not an independent risk factor for $\mathrm{SAH}$ (Table 4).

\section{Discussion}

This study did not show any significant relationship between the $-1562 \mathrm{C} / \mathrm{T}$ polymorphism of the MMP-9 
Table 1. Demographics, risk factor profiles, and MMP-9 genotypes and allele distribution in patients with different ischaemic stroke aetiologies and their matched controls

\begin{tabular}{|c|c|c|c|c|c|c|c|}
\hline Risk factor & $\begin{array}{c}\text { SVD stroke } \\
(n=100) \\
(24 \% \text { of all } \\
\text { ischaemic stroke) }\end{array}$ & $\begin{array}{c}\text { LVD stroke } \\
\text { ( } n=96) \\
(23 \% \text { of all } \\
\text { ischaemic stroke) }\end{array}$ & $\begin{array}{c}\text { CE stroke } \\
(n=222) \\
(53 \% \text { of all } \\
\text { ischaemic stroke) }\end{array}$ & $\begin{array}{l}\text { Controls } \\
(n=408)\end{array}$ & $\begin{array}{c}P \text {-value } \\
\text { for } \\
\text { SVD stroke vs. } \\
\text { controls }\end{array}$ & $\begin{array}{c}\text { P-value } \\
\text { for } \\
\text { LVD stroke vs. } \\
\text { controls }\end{array}$ & $\begin{array}{c}\text { P-value } \\
\text { for } \\
\text { CE stroke vs. } \\
\text { controls }\end{array}$ \\
\hline Age, years $($ mean $\pm \mathrm{SD})$ & $62.8 \pm 11.9$ & $66.3 \pm 11.6$ & $70.2 \pm 13.4$ & $64.4 \pm 18.4$ & NS & NS & NS \\
\hline Sex, male/female ratio & $57 / 43$ & $61 / 35$ & $87 / 135$ & $195 / 213$ & NS & NS & NS \\
\hline Hypertension, $n(\%)$ & $77(77.0)$ & $79(82.3)$ & $189(85.1)$ & $177(43.4)$ & 0.0011 & 0.0003 & $<0.00001$ \\
\hline Ischaemic heart disease, $n(\%)$ & $29(29.0)$ & $40(41.7)$ & $170(76.6)$ & $105(25.7)$ & NS & 0.026 & $<0.00001$ \\
\hline Atrial fibrillation ${ }^{\dagger}, n(\%)$ & $0(0)$ & $0(0)$ & $159(71.6)$ & $32(7.8)$ & 0.0054 & 0.0064 & $<0.00001$ \\
\hline Hypercholesterolaemia, $n(\%)$ & $62(62.0)$ & $61(63.5)$ & $101(45.5)$ & $66(16.2)$ & $<0.00001$ & $<0.00001$ & $<0.00001$ \\
\hline Diabetes mellitus, $n(\%)$ & $19(19.0)$ & $19(19.8)$ & $34(18.2)$ & $1(0.2)$ & $<0.00001$ & $<0.00001$ & $<0.00001$ \\
\hline Smoking (current/previous), $n(\%)$ & $41(41.0)$ & $41(42.7)$ & $51(27.3)$ & $148(36.3)$ & NS & NS & 0.0119 \\
\hline \multicolumn{5}{|l|}{ Genotype } & \multirow{4}{*}{$\begin{array}{l}\text { NS* } \\
\text { NS** }^{*}\end{array}$} & \multirow{4}{*}{$\begin{array}{l}\text { NS* } \\
\text { NS** }\end{array}$} & \multirow{4}{*}{$\begin{array}{l}\mathrm{NS}^{*} \\
\mathrm{NS}^{* *}\end{array}$} \\
\hline $\mathrm{CC}, n(\%)$ & $79(79.0)$ & $67(69.8)$ & $169(76.1)$ & $291(71.3)$ & & & \\
\hline $\mathrm{CT}, n(\%)$ & $19(19.0)$ & $25(26.0)$ & $45(20.3)$ & $111(27.2)$ & & & \\
\hline $\mathrm{TT}, n(\%)$ & $2(2.0)$ & $4(4.2)$ & $8(3.6)$ & $6(1.5)$ & & & \\
\hline \multicolumn{5}{|l|}{ Allele } & \multirow{3}{*}{ NS*** } & \multirow{3}{*}{ NS*** } & \multirow{3}{*}{ NS**** } \\
\hline $\mathrm{C}, n(\%)$ & $177(88.5)$ & $159(82.8)$ & $383(86.3)$ & $693(84.9)$ & & & \\
\hline $\mathrm{T}, n(\%)$ & $23(11.5)$ & $33(17.2)$ & $61(13.7)$ & $123(15.1)$ & & & \\
\hline
\end{tabular}

SVD stroke indicates small vessel disease stroke, LVD stroke indicates large vessel disease stroke, CE stroke indicates cardioembolic stroke; SD indicates standard deviation

tatrial fibrillation was not considered as a risk factor for $L V D$ stroke and SVD stroke

* statistical calculation based on the comparison of CC vs. CT and TT genotypes ( $\chi^{2}$ test)

** statistical calculation based on the comparison of CC and CT vs. TT genotypes ( $\chi^{2}$ test)

*** statistical calculation based on the comparison of $C$ vs. Talleles $\left(\chi^{2}\right.$ test $)$ 


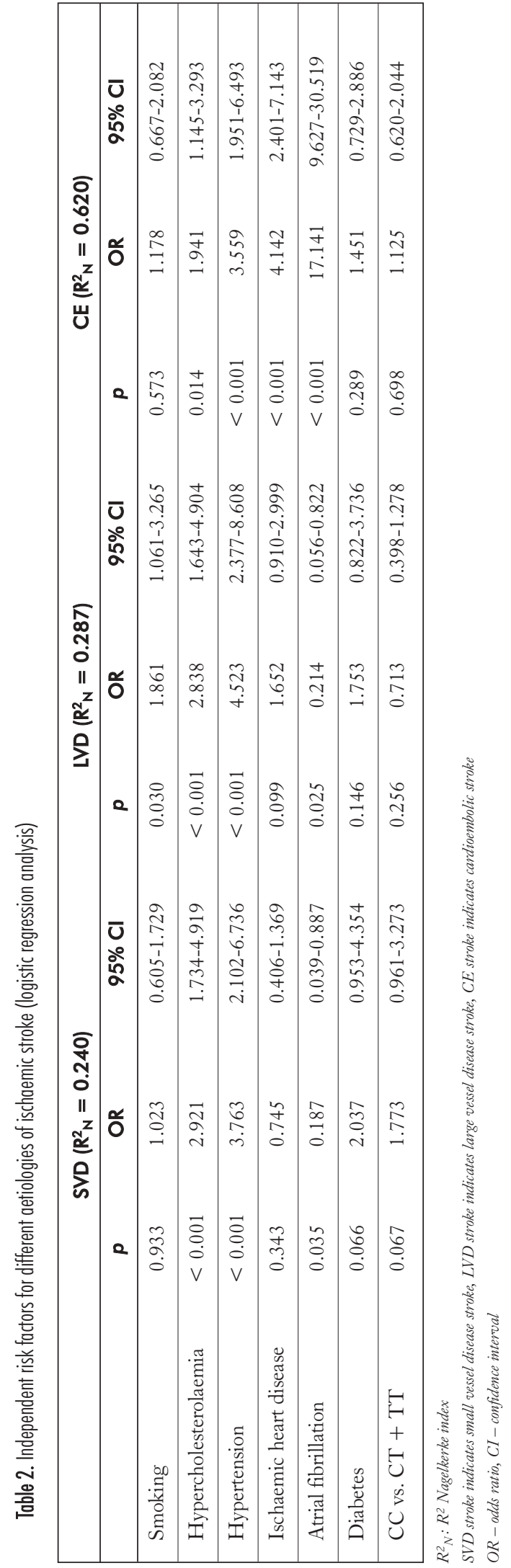

gene and ischaemic stroke (regardless of aetiology), ICH and SAH from ruptured aneurysm.

So far, MMP-9 has been extensively studied in plaque formations in coronary and carotid arteries.

Matrix metalloproteinases influence the process of plaque formation by facilitating migration of vascular smooth cells into the intimal space. They also degrade the fibrous cap, causing rupture of the plaque [19]. A study performed by Loftus et al. showed an increased level of MMP-9 in unstable carotid plaques as compared to stable carotid plaques [20] and a correlation between the MMP-9 levels in plasma with carotid plaque instability [21]. Studies in patients with ischaemic heart disease proved more severe coronary atherosclerosis evaluated by angiography in patients carrying one or two copies of the $\mathrm{T}$ allele [3]. Coronary artery disease and large vessel disease stroke present with common pathophysiological features; both are the result of plaque formation. Therefore, we speculated that the $M M P-9 \mathrm{C} / \mathrm{T}$ polymorphism might also affect the risk of stroke due to LVD.

There are a few explanations for the lack of association between the $\mathrm{C} / \mathrm{T}$ polymorphism and the risk of LVD in the present study. It may be due to the fact that many $\mathrm{T}$ allele carriers died before the development of LVD stroke. As a result, the prevalence of ischaemic heart disease in the cases was similar to that in the controls. It cannot be excluded that the lack of significance of the studied polymorphism in LVD stroke is a consequence of the activity of unknown factors modifying the function of MMP-9 more strongly than the polymorphism. The lack of association between the studied polymorphism and ischaemic stroke, both due to LVD and other aetiologies, in our study may support the hypothesis of Montaner et al. [22] that this polymorphism is not functional in cerebral ischaemia in vivo. However, this study was based on a small number of patients with stroke mostly of cardioembolic aetiology. Those authors also found that high plasma levels of MMP-9 did not correlate with presence of the $T$ allele but with the theoretically low-function alleles (CC) in their studied group.

Engagement of MMP-9 in the pathogenesis of $\mathrm{ICH}$ was documented in animal studies on ICH due to cerebral amyloid angiopathy. These experiments showed increased production of MMP-9 in cerebral endothelial cells in mice stimulated by amyloid-beta peptide or in transgenic mice with overexpression of Swedish mutation of amyloid precursor protein (APPsw) [23]. Other animal data showed a correlation between MMP-9 in rat brain using zymography and damage of the blood-brain barrier [24]. They also showed that brain oedema follow- 
Table 3. Demographics, risk factor profiles, and MMP-9 genotypes and allele distribution in patients with ICH, SAH and their matched controls

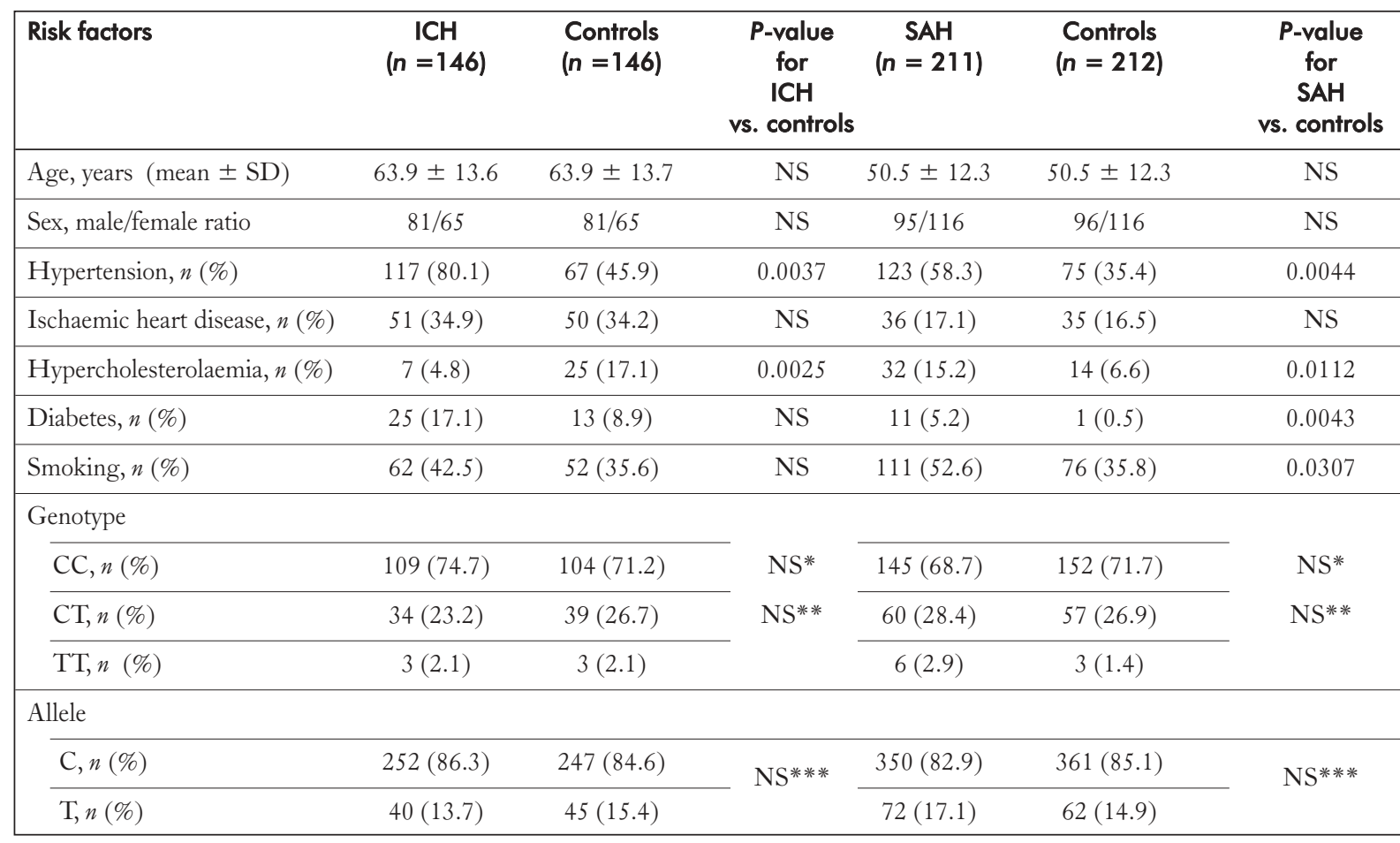

ICH indicates intracerebral haemorrhage, SAH indicates subarachnoid haemorrhage, SD indicates standard deviation

* statistical calculation based on the comparison of CC vs. CT and TT genotypes ( $\chi^{2}$ test)

*** statistical calculation based on the comparison of CC and CT vs. TT genotypes ( $\chi^{2}$ test)

**** statistical calculation based on the comparison of allele $C$ vs. $T\left(\chi^{2}\right.$ test $)$

ing ICH can be weakened by a specific MMP-9 inhibitor $[25,26]$. Studies in humans showed that the level of MMP-9 in plasma correlated with the volume of oedema due to ICH haemorrhage [27] and with worsening of the neurological deficit [14]. Since the studied polymorphism affects enzymatic activity we postulated that it can be a risk factor for developing ICH. The negative results of our study can be explained by the different role of MMP-9, more a marker of the severity of brain oedema than a risk factor of $\mathrm{ICH}$. Another explanation may be that they are due to selection bias, which will be mentioned below.

To date the $-1562 \mathrm{C} / \mathrm{T}$ polymorphism of the $M M P-9$ gene has been examined in two studies in patients with SAH due to ruptured aneurysm $[15,16]$. Despite the negative results of the previous and the current studies, we cannot exclude the possible role of MMP-9 in aneurysmal SAH. MMP-9 has proteolytic activity against elastin and collagen IV, a major component of the basement membrane that surrounds vascular smooth muscle cells and underlies the endothelium in the blood vessel wall [3]. It has been demonstrated that the development and rupture of aneurysms is associated with collagen and elastin degradation. Elastin proteolysis is mostly related to vessel wall dilatation, while collagen degradation is more important in aneurysmal rupture [7]. Interestingly, increased expression of MMP-9 was observed in abdominal aortic aneurysm.

The lack of a correlation between the $-1562 \mathrm{C} / \mathrm{T}$ $M M P-9$ polymorphism and the risk of cerebrovascular disease in our study could be explained by the fact that elevation of MMP-9 in stroke, ICH and aneurysmal SAH may not be determined by a genetic variant of the MMP-9 gene, but could be a result of its uncontrolled release due to other non-specific factors $[28,29]$. It cannot be excluded that other non-genetic mechanisms may influence the overexpression of MMP-9. These mechanisms consist of (1) regulation of transcription by interleukin-1 (IL-1), platelet-derived growth factor (PDGF), tumour necrosis factor- $\alpha$ $(\mathrm{TNF}-\alpha)$, and epidermal growth factor (EGF) through several cis elements including 2 AP-1 sites, the PEA3 motif, and the consensus sequence for binding of nuclear factor-kB; (2) inhibition of MMP-9 activity by tissue 
Table 4. Independent risk factors for ICH and SAH (logistic regression analysis)

\begin{tabular}{|lcccccc|}
\hline & \multicolumn{3}{c}{$\mathbf{I C H}\left(\mathbf{R}_{\mathbf{N}}=\mathbf{0 . 2 0 9}\right)$} & \multicolumn{3}{c|}{$\mathbf{S A H}_{\left(\mathbf{R}_{\mathbf{N}} \mathbf{~} \mathbf{0 . 1 5 4}\right)}$} \\
\hline & $\mathbf{p}$ & $\mathbf{O R}$ & $\mathbf{9 5 \%} \mathbf{C l}$ & $\mathbf{p}$ & $\mathbf{O R}$ & $\mathbf{9 5 \%} \mathbf{C l}$ \\
\hline Smoking & 0.190 & 0.709 & $0.423-1.186$ & $<0.001$ & 2.111 & $1.451-3.071$ \\
\hline Hypercholesterolaemia & 0.775 & 1.075 & $0.654-1.768$ & $<0.001$ & 0.339 & $0.211-0.545$ \\
\hline Hypertension & $<0.001$ & 6.513 & $3.748-11.318$ & $<0.001$ & 2.965 & $2.005-4.384$ \\
\hline Ischaemic heart disease & 0.991 & 1.003 & $0.581-1.732$ & 0.038 & 0.597 & $0.366-0.972$ \\
\hline Atrial fibrillation & 0.080 & 0.390 & $0.136-1.118$ & - & - & - \\
\hline Diabetes & 0.406 & 1.349 & $0.666-2.729$ & 0.436 & 0.742 & $0.350-1.574$ \\
\hline CC vs. CT + TT & 0.728 & 1.095 & $0.655-1.830$ & 0.666 & 0.917 & $0.621-1.356$ \\
\hline
\end{tabular}

$R^{2}{ }_{N}: R^{2}$ Nagelkerke index

ICH indicates intracerebral haemorrhage SAH indicates subarachnoid haemorrhage

$O R$ - odds ratio; $C I$ - confidence interval

inhibitors of metalloproteinases (TIMPs); and (3) regulation of active MMP-9 level by TIMPs or other inhibitors such as alpha 2-macroglobulin or alpha 1-antitrypsin [22]. Thus, different mechanisms such as regulation of transcription, activation of latent MMPs and inhibition of MMP-9 activity by TIMPs can influence the impact of an MMP on extracellular matrix degradation [22].

Ischaemic stroke, $\mathrm{ICH}$ and aneurysmal $\mathrm{SAH}$ are common multifactorial diseases. The genetic factor, i.e. -1562 C/T MMP-9 polymorphism, may be insignificant when present alone. However, its co-occurrence with other common clinical risk factors in the same subject can give rise to a highly significant risk of a disease. Certain classical clinical risk factors indicate a much higher risk for those patients who are carriers of certain genetic mutations [30]. We cannot exclude that interactions between $-1562 \mathrm{C} / \mathrm{T} M M P-9$ genotypes and certain clinical risk factors can increase the relative risk for some types of cerebrovascular disease.

A potential limitation of our study, as in all studies on genetic risk factors, is a selection bias related to loss of the most severely affected patients. In our current study $10 \%$ of ischaemic stroke patients, $20 \%$ of $\mathrm{ICH}$ patients, and $25 \%$ of SAH patients did not fulfil the inclusion criteria. We are also aware that some patients die before admission to the hospital, i.e. $15 \%$ of $\mathrm{SAH}$ patients [31]. It is possible that the most severely affected patients have a different genetic profile and it could influence the final result.

We did not take into consideration the plausible influence of medication, e.g. aspirin, on the phenotypic effect of $-1562 \mathrm{C} / \mathrm{T} M M P-9$ polymorphism. It would be interesting to study the genotype-phenotype correlations of the MMP-9 gene in aspirin users/non-users and other ischaemic stroke patient subpopulations.

\section{Conclusion}

The $-1562 \mathrm{C} / \mathrm{T}$ polymorphism of the MMP-9 gene is not associated with the risk of ischaemic stroke, aneurysmal SAH, or ICH.

\section{Disclosure}

Authors report no conflict of interest.

\section{References}

1. Nagase H., Woessner J.F. Matrix metalloproteinases. JBC 1999; 274: 21491-21494.

2. Ye S. Polymorphism in matrix metalloproteinase gene promoters: implication in regulation of gene expression and susceptibility of various diseases. Matrix Biology 2000; 19: 623-629.

3. Zhang B., Ye S., Herrmann SM., et al. Functional polymorphism in the regulatory region of gelatinase $\mathrm{B}$ gene in relation to severity of coronary atherosclerosis. Circulation 1999; 99: 17881794.

4. Kaplan R.C., Smith N.L., Zucker S., et al. Matrix metalloproteinase-3 (MMP3) and MMP9 genes and risk of myocardial infarction, ischemic stroke, and hemorrhagic stroke. Atherosclerosis 2008; 201: 130-137.

5. Fornage M., Mosley T.H., Jack C.R., et al. Family-based association study of matrix metalloproteinase- 3 and -9 haplotypes with susceptibility to ischemic white matter injury. Hum Genet 2007; 120: 671-680 
6. Yasmin C.M., McEniery K.M., Oshaughnessy P.H., et al. Variation in the human matrix metalloproteinase- 9 gene is associated with arterial stiffness in healthy individuals. Arterioscler Thromb Vasc Biol 2006; 26: 1799-1805.

7. Ye S. Influence of matrix metalloproteinase genotype on cardiovascular disease susceptibility and outcome. Cardiovasc Res 2006; 69: 636-645.

8. Lijnen R.H. Metalloproteinases in development and progression of vascular disease. Pathophysiol Haemost Thromb 2003/2004; 33: $275-281$

9. Galis Z.S., Sukhova G.K., Lark M.W., et al. Increased expression of matrix metalloproteinases and matrix degrading activity in vulnerable regions of human atherosclerotic plaques. $J$ Clin Invest 1994; 94: 2493-2503.

10. Kim S.C., Sngh M., Huang J., et al. Matrix metalloproteinase-9 in cerebral aneurysms. Neurosurgery 1997; 4: 642-647.

11. Montaner J., Alvarez-Sabin J., Molina C.A., et al. Matrix metalloproteinase expression after human cardioembolic stroke. Stroke 2001; 32: 1759-1766.

12. Montaner J., Alvarez-Sabin J., Molina C.A., et al. Matrix metalloproteinase expression is related to hemorrhagic transformation after cardioembolic stroke. Stroke 2001; 32: 2762-2767.

13. Costelannos M., Leira R., Serena J., et al. Plasma metalloproteinase-9 concentration predicts hemorrhagic transformation in acute ischemic stroke. Stroke 2003; 34: 40-46.

14. Abilleira S., Montaner J., Molina C.A., et al. Matrix metalloproteinase- 9 concentration after spontaneous intracerebral hemorrhage. J Neurosurg 2003; 99: 65-70.

15. Zhang B., Dhillon S., Geary I., et al. Polymorphism in matrix metalloproteinase-1,-3,-9,-12 genes in relation to subarachnoid hemorrhage. Stroke 2001; 32: 2198-2202.

16. Pannu H., Kim D.H., Guo D., et al. The role of MMP-2 and MMP-9 polymorphisms in sporadic intracranial aneurysms. J Neurosurg 2006; 105: 418-423.

17. Adams H.P, Bendixen B.H, Kappelle L.J., et al. Classification of subtype of acute ischemic stroke. Definitions for use in a multicenter clinical trial. TOAST. Trial of Org 10172 in Acute Stroke Treatment. Stroke 1993; 24: 35-41.

18. Alberti K.G, Zimmet P.Z. Definition, diagnosis and classification of diabetes mellitus provisional proposal of WHO consultation. Diabet Med 1998; 15: 539-553.

19. Jones C.B., Sane D.C., Herrington D.M. Matrix metalloproteinases: a review of their structure and role in acute coronary syndrome. Cardiovasc Res 2003; 59: 812-823.

20. Loftus I.M., Naylor R.A., Goodall S., et al. Increased matrix metalloproteinase-9 activity in unstable carotid plaques. Stroke 2000; 31: 40-47.

21. Loftus I.M., Naylor R.A., Bell P.R., et al. Plasma MMP-9 a marker of carotid plaque instability. Eur J Vasc Surg 2001; 21: 17-21.

22. Montaner J., Fernandez-Cadenas I., Molina C.A., et al. Safety profile of tissue plasminogen activator treatment among stroke patients carrying a common polymorphism $(\mathrm{C}-1562 \mathrm{~T})$ in the promoter region of the matrix metalloproteinase-9 gene. Stroke 2003; 34: 2851-2855.

23. Lee J.M., Yin K., Hsin I., et al. Matrix metalloproteinase-9 and spontaneous hemorrhage in an animal model of cerebral amyloid angiopathy. Ann Neurol 2003; 54: 379-382.
24. Rosenberg G.A., Estrada E.Y., Dencoff J.E. Matrix metalloproteinases and TIMPs are associated with blood-brain barrier opening after reperfusion in rat brain. Stroke 1998; 29: 21892195.

25. Wang J., Tsirka S.E. Neuroprotection by inhibition of matrix metalloproteinases in a mouse model of intracerebral haemorrhage. Brain 2005; 128: 1622-1633.

26. Rosenberg G., Navratil M. Metalloproteinase inhibition blocks edema in intracerebral hemorrhage in the rat. Neurology 1997; 48: 921-926.

27. Alvarez-Sabin J., Delgado P., Abilleira S., et al. Temporal profile of matrix metalloproteinases and their inhibitors after spontaneous intracerebral hemorrhage. Stroke 2004; 35: 1316-1322.

28. Demestre M., Parkin-Smith G., Petzold A., et al. The pro and the active form of matrix metalloproteinase- 9 is increased in serum of patients with amyotrophic lateral sclerosis. $J$ Neuroimmunol 2005; 159: 146-154.

29. Beuche W., Yushchenko M., Mäder M., et al. Matrix metalloproteinase-9 is elevated in serum of patients with amyotrophic lateral sclerosis. Neuroreport 2000; 11: 3419-3422.

30. Szolnoki Z., Somogyvári F., Kondacs A., et al. Evaluation of the modifying effects of unfavourable genotypes on classical clinical risk factors for ischaemic stroke. J Neurol Neurosurg Psychiatry 2003; 74: 1615-1620.

31. Hop J.W., Rinkel G.J., Algra A., et al. Case-fatality rates and functional outcome after subarachnoid hemorrhage: a systematic review. Stroke 1997; 28: 660-664. 